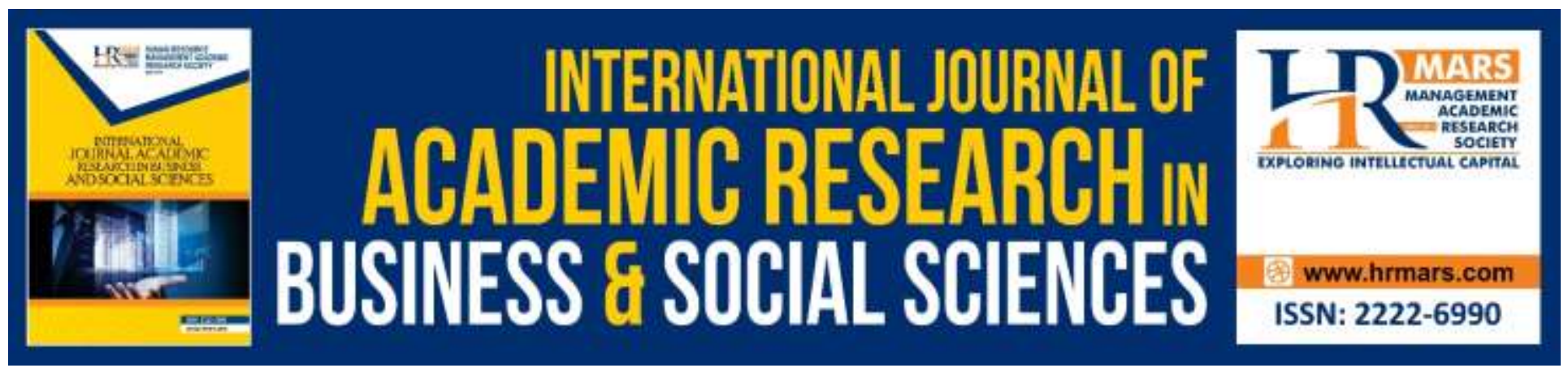

\title{
Analysis of Game Elements in Digital Educational Game According to Gagne Nine Events of Instruction
}

Ummu Husna Azizan, Maizatul Hayati Mohamad Yatim, Laili Farhana Ibharim, Nor Zuhaidah Mohamed Zain

To Link this Article: http://dx.doi.org/10.6007/IJARBSS/v9-i7/6097

DOI: $10.6007 /$ IJARBSS/v9-i7/6097

Received: 02 May 2019, Revised: 01 June 2019, Accepted: 20 June 2019

Published Online: 26 July 2019

In-Text Citation: (Azizan, Yatim, Ibharim, \& Zain, 2019)

To Cite this Article: Azizan, U. H., Yatim, M. H. M., Ibharim, L. F., \& Zain, N. Z. M. (2019). Analysis of Game Elements in Digital Educational Game According to Gagne Nine Events of Instruction. International Journal of Academic Research in Business and Social Sciences, 9(7), 131-135.

Copyright: (C) 2019 The Author(s)

Published by Human Resource Management Academic Research Society (www.hrmars.com)

This article is published under the Creative Commons Attribution (CC BY 4.0) license. Anyone may reproduce, distribute, translate and create derivative works of this article (for both commercial and non-commercial purposes), subject to full attribution to the original publication and authors. The full terms of this license may be seen

at: http://creativecommons.org/licences/by/4.0/legalcode

Vol. 9, No. 7, 2019, Pg. 131 - 135

http://hrmars.com/index.php/pages/detail/IJARBSS

JOURNAL HOMEPAGE

Full Terms \& Conditions of access and use can be found at http://hrmars.com/index.php/pages/detail/publication-ethics 


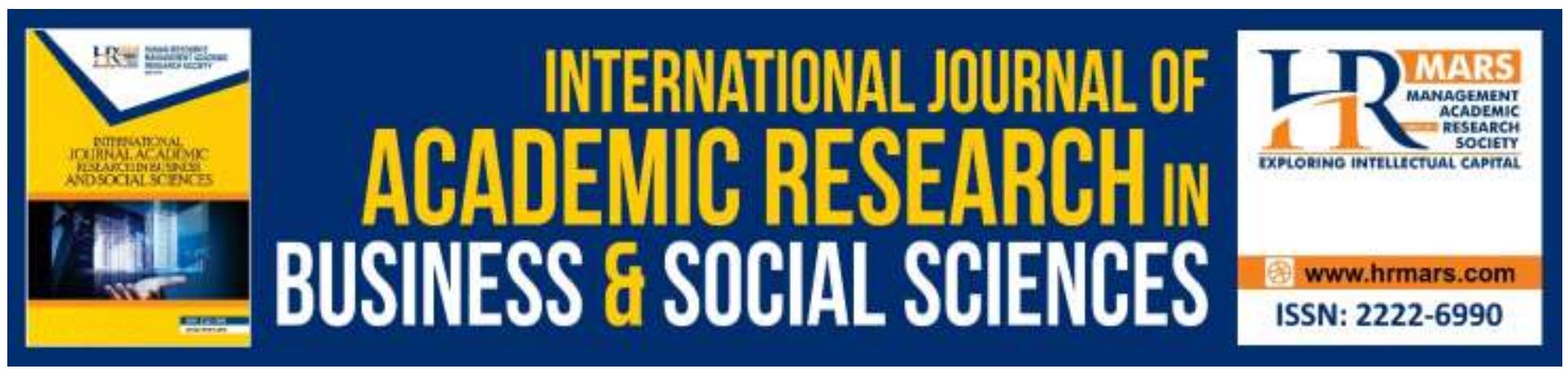

\title{
Analysis of Game Elements in Digital Educational Game According to Gagne Nine Events of Instruction
}

\author{
Ummu Husna Azizan, Maizatul Hayati Mohamad Yatim, Laili \\ Farhana Ibharim, Nor Zuhaidah Mohamed Zain \\ Faculty of Arts, Computing and Creative Industry, Sultan Idris Education University, PO box \\ 35900 Tanjung Malim, Perak, Malaysia
}

\begin{abstract}
The purpose of this study is to analyze the game elements based on Gagne Nine Events of Instruction and to develop instrument which will be use to analyze the game elements needed in the development of digital educational games. The study was conducted using qualitative design where the interview and observation involved. A total of 20 students from a school in Tanjong Malim Perak participated in this survey. The findings of the study show that eight game elements are analyzed based on Gagne Nine Events of Instruction that are mystery, action, challenge, being at risk, uncertainty of outcome, opportunity for mastery, visible signs of progress and emotional content. These elements will be aligned with Gagne Nine Events of Instruction to develop an instrument. In conclusion, this study will further enhance the digital educational games design process and further promote innovation in teaching and learning in line with the Malaysian Education Blueprint 20132025.
\end{abstract}

Keywords: Game Elements, Gagne Nine Events of Instruction, Instrument, Digital Educational Games, Game Design

\section{Introduction}

Digital educational games are an exciting approach to provide full of knowledge building of teaching and learning environment. Although digital educational games have the potential to encourage motivation and student engagement in learning, in terms of digital educational games design and development are still in its early stages (Hsu \& Tsai, 2013). The design of the game especially the digital educational games need to emphasize the elements of the game that are relevant to the purpose of the game development.

Game design is a very important part of the development process because if the game is designed correctly it can be an ideal context to engage students in abstract thinking and complex concepts (Barab et al., 2009). Previous researchers have developed various forms of digital games that are conceptualized in education. However, there are many lacking in the design of digital educational 
games that have been developed. Wan Fatimah and Hidayah (2010) have developed digital educational games but that game does not include feedback or help elements where feedback is an essential element of the game. Lee (2009) also had developed the Tower Trap game to learn mathematics but the game is not include with feedback that motivate players.

This situation clearly shows that digital educational game design is still at a weak level as the designer does not emphasize the game elements that need to exist in a digital educational game. Hence, this study was developed to design digital educational games that meet the needs of students. When the educational games was appropriately designed, it will enhance the motivation of teachers and students to use digital educational games in teaching and learning. This also coincides with the Malaysia Education Blueprint 2013-2025 where the use of technology is encouraged to innovate in delivering teaching. This can be realized when the Transformasi Nasional 2050 states to give tablet to 430000 teachers in Malaysia.

\section{Problem Statement}

In recent years digital educational games have earned attention from researchers and educators as educational games are designed to teach specific subjects, deepen understanding and help students acquire certain skills while playing especially for low ability students (Milosevic, Milicevic, Besic and Bozovic, 2010). Games are also often identified as a way to increase the interest and concentration of students in the classroom (Facer, 2003; Squire and Jenkins, 2003).

The design of a learning environment built with the characteristics of digital educational games can enhance student-centered learning by providing challenges and promoting co-operation, involvement, and problem solving strategies (Gros, 2007). According to Allen (2007), successful design techniques of digital games must have all the game elements to ensure meaningful learning to each student.

A study conducted by Jonker, et al. (2009) found that game-based educational software promotes student engagement in learning activities. They found that the feedback provided enables students to know whether their answers are correct or wrong and the rewards given increase the students' motivation to continue playing. However, the game has no challenge for questions and do not provide help or tips will give difficulties especially to lower-ability students (Jonker et al., 2009).

There are a number of deficiencies and a large number of disparities, especially in terms of design elements, as earlier researchers did not incorporate those game elements and did not take into account the needs of different students ability in the development of digital educational games.

\section{Objective}

The main objective of this study is to analyze the game elements based on Gagne Nine Events of Instruction and produce instrument to analyze game elements based on Gagne Nine Events of Instruction.

\section{Methodology}

This research uses qualitative designs such as interview and observation. Interview and observation were used to see how the students identify the game elements in digital games. These two methods are used because researcher need to examine in detail how the students analyze the game elements 
based on Gagne Nine Events of Instruction. Interview and observation were conducted on students using digital games to analyze game elements based on Gagne Nine Events of Instruction. Checklist is provided to help researchers record the elements. Based on observation result, the instrument for analyzing game elements based on Gagne Nine Events of Instruction was developed. This instrument was validate by instructor of instructional technology expert. This research involving 20 secondary school students aged between 14 to 15 years around Tanjung Malim who are randomly selected. This students will be interviewed by researcher after they use the existing digital educational games in today educational world.

\section{Findings and Discussion}

The findings show that eight elements of the game are analyzed based on the Gagne Nine Events of Instruction which are mystery, action, challenge, being at risk, uncertainty of outcome, opportunity for mastery, visible signs of progress and emotional content.

Based on the observation and interview, 14 students were able to identify mystery, action, challenge and being at risk element in digital educational game that they play. While 10 students were able to identify visible signs of progress and emotional content element in digital educational games that they play. Next, only 8 students were able to identify the element of uncertainty of outcome and opportunity for mastery. The finding from interview and observation have also found that many students less skillful in identifying game elements in digital educational games that have been played. Therefore, an instrument for analyzing game elements based on Gagne Nine Events of Instruction was developed by researchers to facilitate students and digital game developers to develop a quality and effective digital educational games to players when used. The instrument consists of nine parts based on the Gagne Nine Events of Instruction.

\section{Conclusions}

The findings show that eight elements of game that have been analyzed: Mystery, action, challenge, being at risk, uncertainty of outcome, opportunity for mastery, visible signs of progress and emotional content. These elements need to be parallel to Gagne Nine Events of Instruction in the development of digital educational games. Therefore digital educational games developer need to include all these elements when developing digital educational games in future. The researcher also have been developed an instrument for analyzing the game elements that required in the design of a digital educational games. This study also give a positive impact on students and teachers where teachers can use innovation in teaching using a well-designed digital educational game for students understanding in line with the goals of the Malaysia Education Blueprint 2013-2025. This study also has a positive impact on societies who want to venture into the development of digital educational games because innovation will trigger new ideas that will be transformed into commercial value. This is in line with the National Transformation 2050, where the Cipta 1Malaysia (C1PTA) award is awarded to recognize the most innovative youth at the national level.

\section{Acknowledgement}

This work was financially supported by the Sultan Idris Education University under University Research Grant (2017-0182-109-01). 
INTERNATIONAL JOURNAL OF ACADEMIC RESEARCH IN BUSINESS AND SOCIAL SCIENCES

Vol. 9, No. 7, July, 2019, E-ISSN: 2222-6990 ¿C 2019 HRMARS

\section{Corresponding Author}

Ummu Husna Azizan, Faculty of Arts, Computing and Creative Industry, Universiti Pendidikan Sultan Idris, 35900 Tanjung Malim, Perak, Malaysia

E-mail: ummuhusna@fskik.upsi.edu.my

\section{References}

Allen, M. W. (2007). Designing Successful e-Learning. San Francisco: Pfeiffer.

Barab, S., Scott, B., Siyahhan, S., Goldstone, R., Ingram-Goble, A., Zuiker, S., \& Warren, S. (2009). Transformational play as a curricular scaffold: Using videogames to support science education. Journal of Science Education and Technology, 18(4), 305-320.

Facer, K. (2003). Computer Games and Learning: Why Do We Think it's Worth Talking About Computer Games and Learning in The Same Breath? Retrieved from http://www2.futurelab.org.uk

Gros, B. (2007). Digital Games in Education: The Design of Games-Based Learning Environments. Journal of Research on Technology in Education. 40(1): 23-38.

Hsu, C. Y., \& Tsai, C. C. (2013). Examining the effects of combining self-explanation principles with an educational game on learning science concepts. Interactive Learning Environments, 21(2), 104-115.

Lee, Y. L. (2009). Enhancement of Fractions from Playing a Game. Proceedings of the 32nd Annual Conference of the Mathematics (pp. 323-330). Crossing divides: MERGA 32

Milosevic, D., Milicevic, B., Besic, C., and Bozovic, M. (2010). Applying Educational Games in Primary School Education. Technics Technologies Education Management. 5(4): 693-699.

Squire, K. and Jenkins, H. (2003). Harnessing the Power of Games in Education, InSight. 3: 5-33.

Fatimah, W. A. and Hidayah, N. A. L. (2010). Development of a Mathematic Courseware: Fractions. Perak: Universiti Teknologi PETRONAS. 